\title{
Learning Communication Strategies of Rural Civitas Academica During Covid-19 Pandemic Period
}

\author{
Khoirul Anwar ${ }^{1, *}$ Fitri Amalia Shintasiwi ${ }^{2,}$ Ferani Mulianingsih ${ }^{3}$ \\ ${ }^{1,2,3}$ Social Science Education, Faculty of Social Sciences, UNNES \\ ${ }^{*}$ Corresponding author. Email: irulanwar@mail.unnes.ac.id
}

\begin{abstract}
Covid-19 pandemic is an unpredictable global incident. The impact of the pandemic has spread in various sectors such as the implementation of higher education. The health protocols are stated to suggest people working and studying at home, but it requires basic academic communication. Thus, this research aims to reveal the learning communication strategy of civitas akademica which spread in various rural areas. The researchers used qualitative procedures through interviews, literature reviews, and documentation study. The results show that the lecturers and the students coming from various rural areas in Indonesia use internet-based communication media. The media includeacademic applications provided by the private sector (social media) to support their learning activities.
\end{abstract}

Keywords: Learning Communication, Rural Civitas Academica, Covid-19.

\section{INTRODUCTION}

Unlike in previous times, the development of information and communication technology in this century is in an unpredictable situation. A historian named Pierre Chaunu considers that the new explosion of information and communication technology (ICT) occurred in the second half of the twentieth century shows the most powerful human revolution since the Neolithic era. Humans require three thousand years to perfect writing, but it only needs forty years to launch an informatics revolution [3].

The revolution in the field of informatics has triggered the dynamics of change in various aspects of human life. There has been a change in citizenship status from traditional society/citizen to global society (global village)/netizen. Netizen is a metamorphosis born from a very fast natural transformation process. Thus, this is a historical event that was never expected before. Internet technology is able to create a new world called the galactic network [8].

The emergence of internet technology at the global level has been able to bring significant influence on the patterns of human interaction. Communication between individuals and groups has experienced changes in both space and time aspects. The process of delivering messages that previously took a long time, only requires a second and has been able to be reached very easily today. This phenomenon indicates a highcontextual appearance of culture[5], namely when a person/group of people does not prioritize a wide space/territory in the context of cultural communication.

Most people are able to access information at high speed and it is relatively unobstructed by the existence of space. Indonesia is a country with a high number of internet-based technology device usage[10]. With a total population of around 260 million people, Indonesia has 150 million internet users or around $56 \%$ of the total population. This number is as large as the number of social media users who are actively connected. While the number of active mobile (smartphone) social media users is 130 million or around $48 \%$ of the population. In one day, internetbased social media users spend approximately 8 hours and 36 minutes through various devices on average.

University is an educational institution that cannot avoid the global flow of the development of information technology. The informatics revolution in the field of education has also stimulated universities to transform. Communication between the academic community is no longer dominated by conventional methods based on direct or indirect interaction. The delivery of messages nowadays does not have to be conducted through face-to-face interaction or paperbased letters. University is faced by the challenges of informatics revolution which has to be addressed wisely and by a method that does not impede academic service as its main activity. 


\section{RESEARCH METHOD}

The researcher used qualitative approach in order to collect in-depth overview of the research topic. Data include information of facts collected from observation, so it can be analysed order to understand the phenomena or to support the theory[9]. The source of data can be divided into two categories, namely human and non-human. Human were used as the key informant, and the collected data include soft data. In connection with Covid-19 pandemic, the researchers collected the data online. The informants consist of the lecturers and students at Faculty of Social Sciences, Universitas Negeri Semarang who live in various areas, particularly in 'rural areas'. They were contacted through several communication channels such as email and social media. Secondly, the non-human sources include documents and literatures which are relevant to the research focus. The method of collecting data used two techniques, namely in-depth interviews to lecturers and students; and documentation study[2]. The trustworthiness of data is based on four criteria, that are credibility, transferability, dependability, and confirm ability. Data analysis in this research includes 1) data reduction, categorizing, directing and eliminating unnecessary as well as organizing data; 2) data displays, namely a process of finding meaningful patterns of relationships and providing the possibility of drawing conclusions; and 3) conclusion drawing/verification [4].

\section{COMMUNICATION STRATEGY OF CIVITAS ACADEMICA IN RURAL AREAS DURING COVID-19 PANDEMIC}

Civitas Akademica at Faculty of Social Sciences, Universitas Negeri Semarang who are lecturers and students, are required to obey the health protocols during the Covid-19 pandemics. Related to the suggestion from the government to work and to study at home, this causes most lecturers and students returned to their hometown. They mainly come from (cities/districts, sub-districts, and villages) which spread in Central Java. Others come from West Java, Jakarta, East Java and even Papua. Previously, the lectures held in face-to-face, but then it shifts to virtual learning due to the pandemic. Therefore, the academic communication faces the great challenges.

Internet is a strategic tool used for carrying out academic activities at Universitas Negeri Semarang, including the Faculty of Social Sciences. The academic system that is integrated with the internet has been becoming the core of lecture activities for both lecturers and students. UNNES has an Integrated Academic System (SIKADU) which has been operating for more than a decade since it was firstly used in 2007. This is the momentum of the academic revolution which also directly impacts the academic governance at the Faculty of Social Sciences.

The development of the digital world has led to the use of various systems in the increasingly massive internal UNNES circles. In the second decade of the 21 st century, the world was coloured by the emergence of various internet-based applications that could be personally owned directly. This is concurrent with the existence of the explosion of smartphone production which exceeds the number of population. Everyone can control information, especially for those who consider it as an essential need. The world of digital information has also penetrated the education sector as a need which no less is important.

The combination of the development of digital information and the demands in the education sector has created a new phenomenon. UNNES, as an educational institution, utilizes the momentum of the development of digital information as an opportunity to accelerate academic services. Excellent academic services directly impact the reputation of the institution which is seen from the quality assurance that is reliable with various challenges of the situation.

The Covid-19 pandemic is a real challenge for the stability of the academic services of Universitas Negeri Semarang. Internally, UNNES has attempted to accommodate the need of academic services for lecturers and students to be able to carry out lectures both face-to-face and online learning. Not only in lecture activities, but administrative activities driven by the sector of education personnel are also undertaking extraordinary adjustments. Excellent academic services in the current situation require solid synergy among components in the internal circle of Universitas Negeri Semarang.

In order to ensure the stability of excellent academic services, the role of internet-based communication tools has become increasingly strategic. The health protocol during the Covid-19 pandemic regarding the physical distancing has made internet the 'front guard' in fulfilling the information needs of UNNES academic community, including the Faculty of Social Sciences. Aside from utilizing various systems provided by UNNES, students, lecturers, and education staffs also use other internet-based applications.

\section{DISCUSSION}

Hall and Brown stated that culture is communication, time, and space that can "talk". Human perception of space is human perception of "space" printed and patterned in culture. The cultural difference will lead people to build different cultural frameworks, especially when they define and organize the space. 
This occurs because the concept of space is the knowledge that has been internalized to all people when they are at an unconscious level. A serious failure in communication lies in how individuals understand and organize their knowledge before conducting crosscultural communication[5].

The organizing framework of "space" does not merely display physical space to describe the distance from various "material cultures", but also the "time" which does not merely explain "watches". "Space" and "time" are also intercultural communication systems (Hall in [5]). Edward T. Hall named the study of "space" as "proxemics". Proxemics comes from the words "proximity" (closeness) and "phonemics" as a science or theory that studies individuals' perceptions and attitudes towards the use of "space" for themselves and for others. Proxemic theory is also often referred to as "space anthropology" [5].

According to communication science, proxemics is a sub-category of non-verbal communication study including haptics (touch), kinesics (body movements), vocalics (paralanguage), and chronemics (time structure). Hall (in [5]) stated that cultural dimensions are distinguished based on as following:

1. Context: the degree of involvement of messages or communication information in cultural contexts (low/high context);

2. Space: the way of communication conducted through interpersonal physical space management;

3. Time: the cultural orientation towards time;

4. Information Flow: the structure and speed of message flow among individuals (covert/overt message);

5. Language: the use of language in a certain cultural situation (low/high context culture).

Anthony Giddens stated that when the media allows us to access and to perceive the whole world, modernity not only moves people literally but also indirectly moves their presences that are far from where we are[3]. The influence of international dynamics and sophisticated technological developments have motivated netizens to change their customs and living systems in almost all fields. Internet-based life has made netizens run the wheel of life. The Internet has been considered as "new god" which is believed to save the world from traditional life[8]. Some aspects of life have been touched by the new online-based system, which is a system that utilizes internet-based software that can be connected to various sources from anywhere. Every institution and netizen tend to increase their performances and achievements through the cyberspace system.

Huntington argued that, currently, there is a clash of civilizations that has logical consequences of the existence of cultural elective (culture mixing) which originates from various sources as the result of multicultural phenomena, cultural share, open source, and free access. The speed of ICT has mixed prehistoric and present-day civilizations in seconds. The sovereignty of ICT has marked a change in the status of citizens from village residents to network citizens. ICT also has led to the emergence of the spirit of equality and the loss of control or censorship of uniformity. Therefore, it can be stated that humans have been controlled by a system of value and norm that surrounds them[7].

\section{CONCLUSION}

During the Covid-19 pandemic, all academic communities especially in the Faculty of Social Science, UNNES, are obliged to obey health protocol in order to break the chain of the dangerous virus spread. The health protocol that must be implemented in this situation is that all academics are required to keep undertaking academic obligations even from home. Students and lecturers from various regions in Indonesia have utilized internet technology using various applications available either provided by UNNES or by private communication service providers. The intertwined learning communication has experienced various obstacles such as internet connection that can be accessed easily by academics who live in rural areas.

\section{ACKNOWLEDGMENT}

This research based on our observation in current situation during pandemic outbreak at our institution, Faculty of Social Sciences. We send our gratitude to Faculty of Social Sciences, Universitas Negeri Semarang for funding our research. In addition, we also thank the informants who help us collecting the data.

\section{REFERENCES}

[1] Arikunto, S. (2006). Prosedur Penelitian: Suatu Pendekatan Praktek. Jakarta: Rineka Cipta.

[2] Biklen, R. C. B. and S. K. (2008). Qualitative Research for Education: An Introduction to Theory and Methods. Boston: Allyn and Bacon.

[3] Chaubet, F. (2015). Globalisasi Budaya. Yogyakarta: Jalasutra.

[4] Huberman, M. B. M. and M. A. (2005). Qualitative Data Analysis (2nd ed.). California: Sage Publications.

[5] Liliweri, A. (2016). Konfigurasi Dasar; TeoriTeori Komunikasi Antarbudaya. Bandung: Penerbit Nusa Media. 
[6] Patton, M. (1990). Qualitative Evaluation and Research Methods (2nd ed.). Newbury Park: Sage Publications.

[7] Purwasito, A. (2015a). Komunikasi Multikultural. Yogyakarta: Pustaka Pelajar.

[8] Purwasito, A. (2015b). Netizenship Civilization: Mutation of Citizen to Netizen on
Galactic Network. Surakarta: Soft Power Diplomacy Laboratory.

[9] Sekaran, U. (2007). Research Methods for Business. New York: John Wiley \& Sons, Inc.

[10] Social, W. A. (2019). Digital 2019; Global Digital Yearbook. New York. 